\title{
Role of cation structure in the phytotoxicity of ionic liquids: growth inhibition and oxidative stress in spring barley and common radish
}

\author{
Robert Biczak $^{1}$ (D) - Barbara Pawłowska ${ }^{1} \cdot$ Arkadiusz Telesiński $^{2} \cdot$ Janusz Kapuśniak $^{1}$
}

Received: 24 January 2017 / Accepted: 1 June 2017 / Published online: 22 June 2017

(C) The Author(s) 2017. This article is an open access publication

\begin{abstract}
The present study determines the influence of three ionic liquids (ILs) containing cations with diversified structure on the growth and development of spring barley seedlings and common radish leaves. Increasing amounts of 1-butyl-1methylpyrrolidinium hexafluorophosphate $[\mathrm{Pyrrol}]\left[\mathrm{PF}_{6}\right], 1-$ butyl-1-methylpiperidinium hexafluorophosphate $[\mathrm{Piper}]\left[\mathrm{PF}_{6}\right]$, and 1-butyl-4-methylpyridinium hexafluorophosphate $[\mathrm{Pyrid}]\left[\mathrm{PF}_{6}\right]$ were added to the soil on which both plants were cultivated. The results of this studies showed that the applied ILs were highly toxic for plants, demonstrated by the inhibition of length of plant shoots and roots, decrease of fresh mass, and increase of dry weight content. Common radish turned out to be the plant with higher resistance to the used ILs. The differences in the cation structure did not influence phytotoxity of ILs for spring barley. Furthermore, all ILs led to a decrease of photosynthetic pigments, which was directly followed by decreased primary production in plants. Oxidative stress in plants occurred due to the presence of ILs in the soil, which was demonstrated by the increase of malondialdehyde (MDA) content, changes in the $\mathrm{H}_{2} \mathrm{O}_{2}$ level, and antioxidant enzymes such as superoxide
\end{abstract}

Responsible editor: Philippe Garrigues

Electronic supplementary material The online version of this article (doi:10.1007/s11356-017-9439-x) contains supplementary material, which is available to authorized users.

Robert Biczak

r.biczak@ajd.czest.pl

1 The Faculty of Mathematics and Natural Sciences, Jan Długosz University in Częstochowa, 13/15 Armii Krajowej Av, 42-200 Częstochowa, Poland

2 The Faculty of Environmental Management and Agriculture, West Pomeranian University of Technology, Juliusza Słowackiego st. 17, 71-434 Szczecin, Poland dismutase (SOD), catalase (CAT), and peroxidase (POD). The changes in the chlorophyll contents and the increase of POD activity turned out to be the most significant oxidative stress biomarkers in spring barley and common radish. Both spring barley and radish exposed to ILs accumulated a large amount of fluoride ion.

Keywords Ionic liquids · Phytotoxicity · Oxidative stress · Antioxidant enzyme activity $\cdot$ Photosynthetic pigments

\section{Introduction}

In the last decade, interest on the so-called clean technologies in chemical industry has been increased due to technological and environmental reasons. It gives rise to a continuous search for alternatives to the conventional organic solvents. Ionic liquids may become such an alternative. Their basic features, such as low melting temperatures, low vapor pressure, polarity, high thermal and electrochemical stability, high ionic conductivity, and non-flammability, prevent solvent loss and increase the safety for persons employed in the processes of industrial chemical synthesis. However, the study conducted on the influence of ionic liquids (ILs) on the aquatic and soil environment gives rise to a serious concern about the possibility of a permanent contamination of these ecosystems with the discussed compounds. IL toxicity has been observed in microorganisms, fungi, algae, terrestrial plants, invertebrates, and vertebrates (Pham et al. 2010; Petkovic et al. 2012; Peric et al. 2013; Cvjetko Bubalo et al. 2014b; Feder-Kubis and Tomczuk 2013; Messali et al. 2013).

When large amounts of ILs become available in the market and are used in numerous processes, it should be borne in mind that they will penetrate into the soil environment, where the phenomenon of soil sorption related to the presence of 
humus and inorganic colloids may be limited in the top layer of the soil, close to the roots, posing direct threat to plants. Therefore, numerous publications have been published, evaluating the level of ILs' influence on the growth and development of terrestrial plants (Biczak et al. 2010, 2013, 2014a, 2015; Matzke et al. 2008a, b; Studzińska and Buszewski 2009). In the abovementioned papers, ILs' phytotoxicity was determined primarily on the basis of plant growth inhibition, but as mentioned by Cvjetko Bubalo et al. (2014a), the IL toxicity mechanism has not yet been fully understood. Therefore, a view gains increasing popularity in scientific studies in which ILs' phytotoxicity is related to the generation of oxidative stress in plants by these compounds (Liu et al. 2013, 2014, 2015a, b, 2016a, b; Biczak 2016; Biczak et al. 2016a, 2016b; Pawłowska and Biczak 2016).

An opinion prevails in the scientific literature in which the IL phytotoxicity largely depends on the cation and the length of substituent (Cvjetko Bubalo et al. 2014b; Biczak et al. 2014a; Matzke et al. 2008a, b; Studzińska and Buszewski 2009), while to a lesser extent, it depends on the anion type (Cvjetko Bubalo et al. 2014b; Studzińska and Buszewski 2009; Liu et al. 2016a, b; Biczak et al. 2014b). However, scientific reports on the correlation of IL phytotoxicity and their cations are limited. Only Pham et al. (2016) demonstrated the higher toxicity of ILs with pyridinium cations compared to pyrrolidinium and imidazolium cations in Pseudokirchneriella subcapitata algae. Therefore, the objective of the present study was to determine and compare the toxic effects of ILs with different cation structures to spring barley and common radish. The study focused on relatively popular ILs, which are used in chemical synthesis, electrochemistry, and biotechnological processes, containing hexafluorophosphate anion and the following cations: 1-butyl-1-methylpyrrolidinium, 1butyl-1-methylpiperidinium, and 1-butyl-4-methylpyridinium (Bae et al. 2013; Atta et al. 2016; Elgharbawy et al. 2016). In order to compare the phytotoxicity of these ILs and at the same time demonstrate the effects of cations on IL toxicity, apart from traditional phytotoxicity biomarkers including shoot length, root length, and fresh and dry weight yield, the present study also examined the oxidative stress indicators in the seedlings of spring barley and radish such as the malondialdehyde (MDA) content, $\mathrm{H}_{2} \mathrm{O}_{2}$, photosynthetic pigments, and activity of superoxide dismutase (SOD), peroxidase (POD), and catalase (CAT). Since the used ILs contain $\mathrm{PF}_{6}{ }^{-}$anions, the effect of fluoride ions was evaluated for both spring barley and common radish as fluoroacetate, a harmful compound to plants, may be formed when fluoride is absorbed from the soil (Baunthiyal and Pandey 2012). The choice of spring barley for the study was dictated by the evidence that it is the fourth most common cereal species in production and acreage, and radish is a popular vegetable, enriching the human diet with a number of microelements and macroelements and vitamins (Schubert and Jahren 2011; Dragišić Maksimović et al. 2013; AriasBaldrich et al. 2015).

\section{Materials and methods}

\section{Ionic liquids}

All ILs used in these studies were purchased from SigmaAldrich Chemical Co. Chemical structures and abbreviations of ILs 1-butyl-1-methylpyrolidinium hexafluorophosphate ( $\geq 97.5 \%$ purity), 1-butyl-1-methylpiperidinium hexafluorophosphate ( $\geq 97.5 \%$ purity), and 1-butyl-4methylpyridinium hexafluorophosphate ( $\geq 97.0 \%$ purity) are presented in Fig. 1.

\section{Evaluation of ILs' phytotoxicity}

Determination of phytotoxicity of ILs with different cation structures was performed according to the OECD/OCDE guidelines (2006). The following concentrations of ILs were used: $0,1,10,50,100,400,700$, and $1000 \mathrm{mg}$ of compound per $1 \mathrm{~kg}$ of dry weight (DW) of the soil. When preparing the abovementioned concentrations, appropriate amount of ILs was dissolved in acetone and subsequently mixed with quartz sand. After overhead evaporation of acetone, quartz sand containing ILs was mixed with the soil. Three independent samples were prepared for each concentration of IL.

Following the above procedure, control samples were prepared by adding acetone to the sand, but without ILs. In this study, loam was used as soil. It contained about $11 \%$ of fraction with a diameter of $<0.02 \mathrm{~mm}$ and organic carbon of $9.5 \mathrm{~g} \mathrm{~kg}^{-1}$. The $\mathrm{pH}$ was 6.1. Plastic pots were filled with the prepared medium; thereafter, 20 seeds of spring barley (Hordeum vulgare) and common radish (Raphanus sativus L. radicula Pers.) derived from the same source were added. Seed germination and seedlings' growth (14 days) were carried out under strictly controlled conditions: soil moisture, $70 \%$ ppw; temperature, $20 \pm 2{ }^{\circ} \mathrm{C}$; and constant illumination, $170 \mu \mathrm{mol} \mathrm{m}{ }^{-2} \mathrm{~s}^{-1}$ for $16-\mathrm{h}$ day/8-h night. The experiments were conducted in a vegetation hall, which belongs to the Department of Biochemistry and Ecotoxicology at Jan Długosz University in Częstochowa.

Phytotoxicity of the studied ILs for spring barley and common radish was estimated based on, among others, the yield of fresh weight of seedlings, dry weight content, and length of

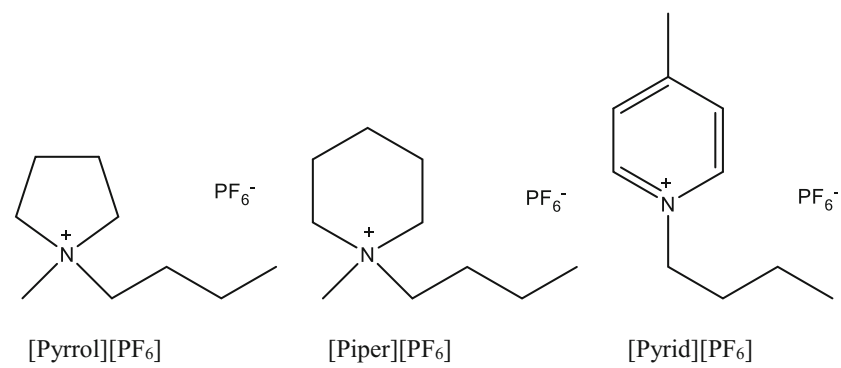

Fig. 1 Structures of the analyzed ILs 
the shoots and roots. The inhibition factor of fresh weight and lengths of shoots and roots were calculated according to the study published by Wang et al. (2009). Using non-linear regression analysis, $\mathrm{EC}_{50}$ was estimated based on the calculated inhibition, with the GraphPad Prism software (GraphPad Software, Inc., La Jolla, CA, USA). Furthermore, both germination potential (GP) and germination rate (GR) of spring barley and common radish seeds were determined. The seeds with longer than 2-mm germ were considered germinated (Liu et al. 2014).

In fresh plant material (spring barley seedlings and common radish leaves), the content of all assimilation pigments, malondialdehyde, $\mathrm{H}_{2} \mathrm{O}_{2}$, and enzymes' activity was determined. In the dried material, the analysis of total fluorine content was performed. Samples treated with high concentrations of ILs were not included in some analyses because the growth inhibition of spring barley and radish shoots was extremely strong at these concentrations.

\section{Determination of total fluoride content}

Based on the method described by Eyde (1982), the total fluoride content in spring barley seedlings and common radish leaves was assessed. Dried and ground samples were fused in nickel crucibles with sodium hydroxide. Water, diluted hydrochloric acid, and citrate buffer solution were added to the melt. Fluoride concentration was determined in the presence of TISAB III buffer using the potentiometric method with an Orion Research ion-selective electrode. The total fluoride content was expressed in $\mathrm{mg} \mathrm{kg}^{-1}$ of DW.

\section{Determination of assimilation pigment content}

According to the methodology presented by Oren et al. (1993), the content of assimilation pigments was determined by spectrophotometry. With the addition of $80 \%$ acetone solution cooled to $4{ }^{\circ} \mathrm{C}$, weighed portion (200 mg) of fresh spring barley seedlings and common radish leaves was homogenized. The resulting extract was transferred into centrifuge tubes and left in the dark for $24 \mathrm{~h}$. The extract was then centrifuged, and in the filtrate, the content of assimilation dyes was determined by measuring the absorbance at 470, 647, and $664 \mathrm{~nm}$. The contents of chlorophylls and carotenoids were expressed in $\mathrm{mg} \mathrm{g}^{-1}$ of dry plant weight (DW).

\section{Determination of malondialdehyde and hydrogen peroxide $\left(\mathrm{H}_{2} \mathrm{O}_{2}\right)$}

With the addition of $0.1 \%$ trichloroacetic acid solution cooled to $4{ }^{\circ} \mathrm{C}$, $500 \mathrm{mg}$ of fresh spring barley seedlings and common radish leaves were homogenized. After centrifugation, MDA and $\mathrm{H}_{2} \mathrm{O}_{2}$ content were determined in the obtained supernatant according to the procedures described by Hodges et al. (1999) and Singh et al. (2007), respectively. As a substrate to determine MDA, thiobarbituric acid was used and the MDA content was determined by measuring the absorbance at 532 and $600 \mathrm{~nm}$. In order to determine the content of $\mathrm{H}_{2} \mathrm{O}_{2}$, the absorbance was measured at a wavelength of $390 \mathrm{~nm}$ for the reaction mixture consisting of supernatant, phosphate buffer ( $\mathrm{pH}$ 7.0), and potassium iodide. The contents of MDA and $\mathrm{H}_{2} \mathrm{O}_{2}$ were calculated using the extinction coefficient equaling $155 \mathrm{mM}^{-1} \mathrm{~cm}^{-1}$ and expressed in $\mu \mathrm{mol} \mathrm{g}^{-1}$ fresh weight (FW).

\section{Determination of superoxide dismutase, catalase, and peroxidase activity}

For the determination of antioxidant enzyme activity, enzymatic extracts were obtained by homogenizing the weighed portion $(500 \mathrm{mg})$ of fresh spring barley seedlings and common radish leaves with the addition of cooled $\left(4{ }^{\circ} \mathrm{C}\right)$ extraction mixture. The mixture contained phosphate buffer ( $\mathrm{pH}$ 7.4), 1 mM EDTA solution, and $0.1 \%$ polyvinylpyrrolidone solution. After centrifugation, the obtained supernatant was also used to determine the protein content.

SOD [EC 1.15.1.1] activity was determined spectrophotometrically by measuring the degree of reduction of nitroblue tetrazolium (NBT) by superoxide anion formed as a result of photochemical reduction of riboflavin in the presence of light (Giannopolitis and Ries 1977). NBT reduction is inhibited by SOD. For determining the activity of SOD, measurement of absorbance of reaction mixture at a wavelength of $560 \mathrm{~nm}$ was performed. SOD activity was expressed as $\mathrm{U} \mathrm{mg}^{-1}$ protein, where $1 \mathrm{U}$ is the amount of enzyme that induces $50 \%$ inhibition of NBT reduction.

CAT activity [EC 1.11.1.6] was determined by the decomposition of $\mathrm{H}_{2} \mathrm{O}_{2}$ by this enzyme during $15 \mathrm{~min}$, and $\mathrm{H}_{2} \mathrm{O}_{2}$ remaining in the reaction mixture was titrated with $0.01 \mathrm{~N}$ $\mathrm{KMnO}_{4}$ (Kar and Mishra 1976). CAT activity was expressed as $\mathrm{U} \mathrm{mg}^{-1}$ protein $\mathrm{min}^{-1}$.

The activity of POD [1.11.1.7] was determined spectrophotometrically by the rate of guaiacol oxidation in the presence of $\mathrm{H}_{2} \mathrm{O}_{2}$ via enzyme occurring in a given volume of extract during $1 \mathrm{~min}$ (Abassi et al. 1998). Absorbance measurement of the reaction mixture at a wavelength of $470 \mathrm{~nm}$ was performed, in order to measure the activity of POD. POD activity was expressed as $\mathrm{U} \mathrm{mg}^{-1}$ protein $\mathrm{min}^{-1}$.

The total protein content necessary to calculate the activity of SOD, CAT, and POD was determined by the Bradford (1976) assay. 


\section{Statistical analysis}

Using two-way analysis of variance, results were subjected to statistical analysis. Tukey's test with $p<0.05$ was used to determine the significance of differences. Data present in tables and figures are expressed as means \pm standard deviation obtained from three measurement replicates.
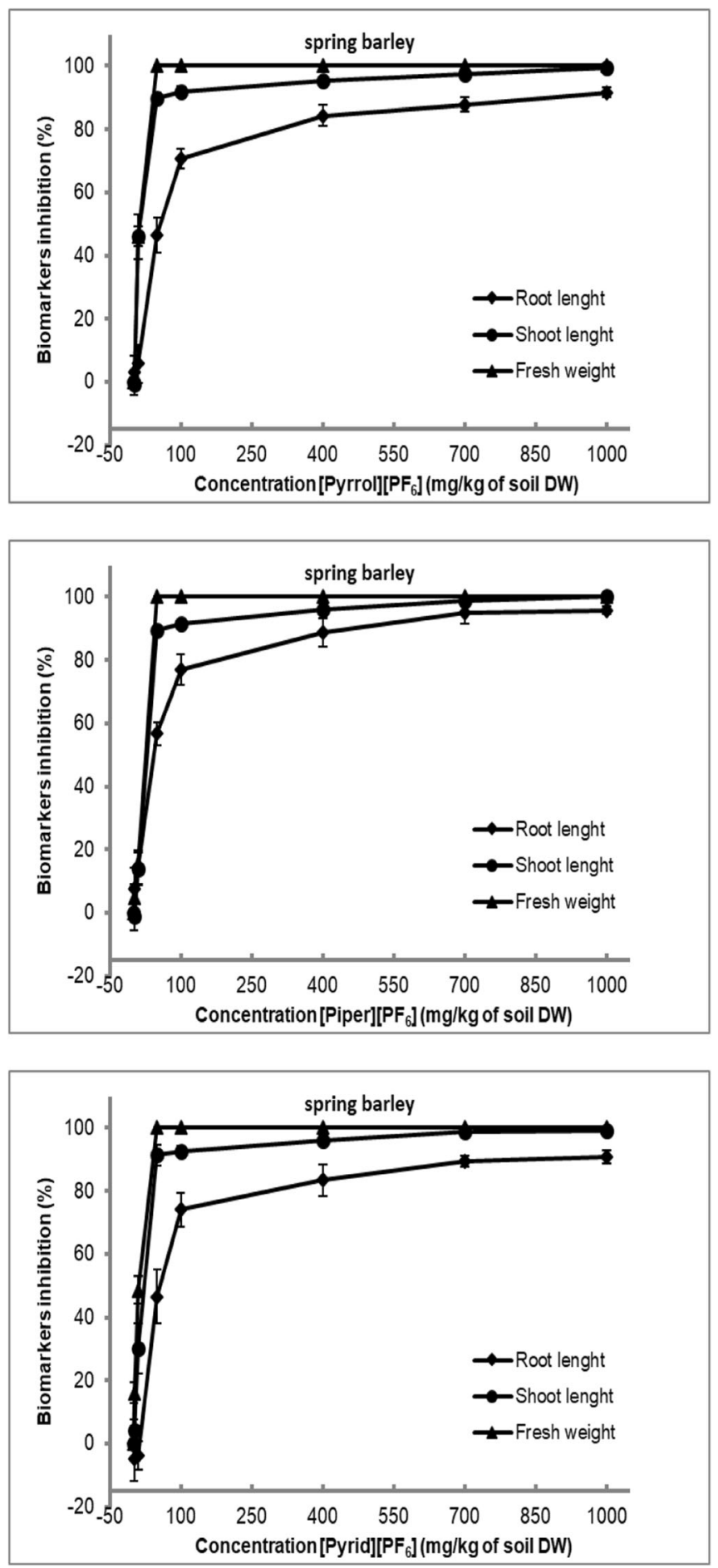

\section{Results and discussion}

\section{Phytotoxicity assay}

The analysis of the obtained results on the influence of the used ILs on the growth and development of spring barley and common radish revealed that all the tested compounds
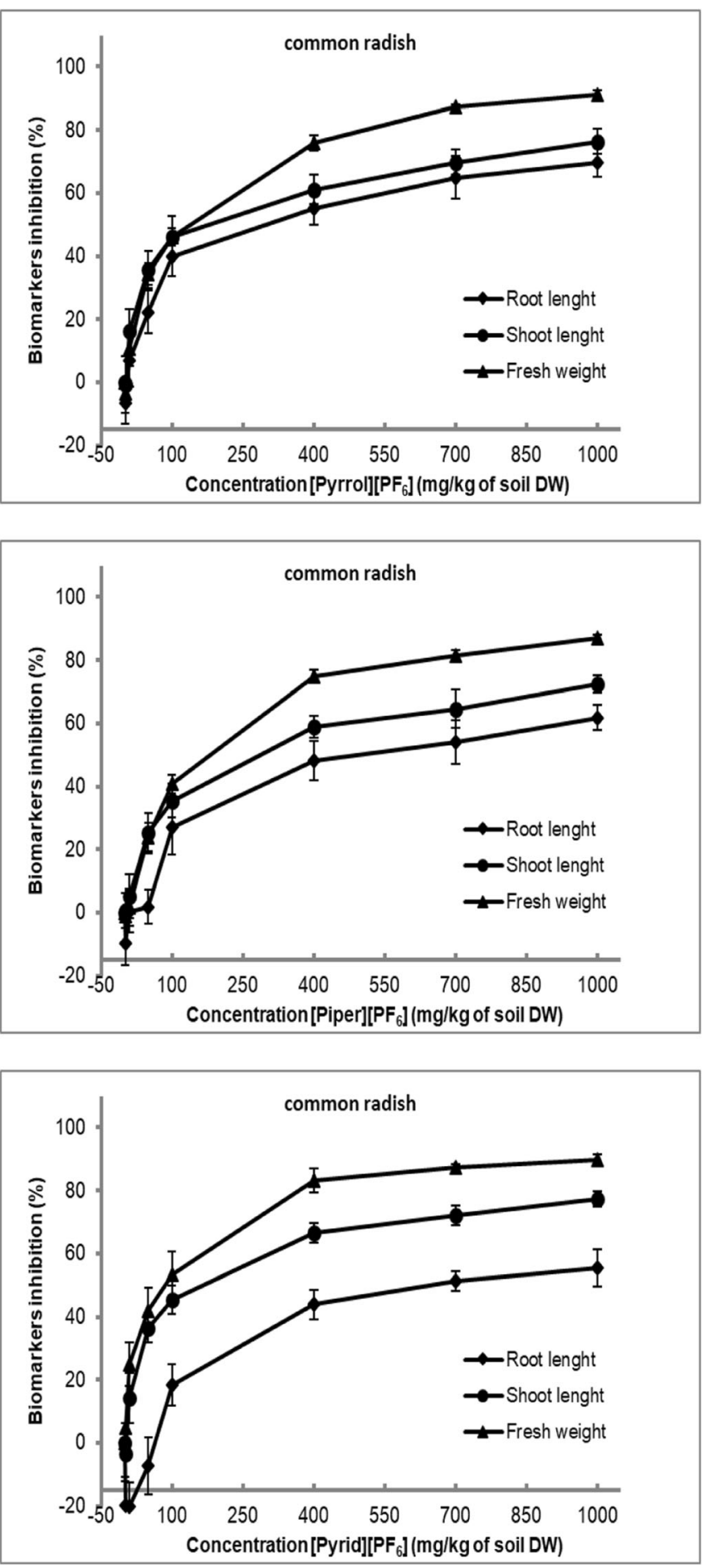

Fig. 2 The inhibition rate (\%) for shoot length, root length, and fresh weight of spring barley and common radish after exposure to ILs 
Table 1 The $\mathrm{EC}_{50}$ values and $95 \%$ confidence intervals for spring barley and common radish following exposure to ILs

\begin{tabular}{|c|c|c|c|c|c|c|}
\hline \multirow[t]{2}{*}{ Biomarkers } & \multicolumn{2}{|l|}{$[$ Pyrrol $]\left[\mathrm{PF}_{6}\right]$} & \multicolumn{2}{|l|}{$[$ Piper $]\left[\mathrm{PF}_{6}\right]$} & \multicolumn{2}{|l|}{$[$ Pyrid $]\left[\mathrm{PF}_{6}\right]$} \\
\hline & $\begin{array}{l}\mathrm{EC}_{50}\left(\mathrm{mg} \mathrm{kg}^{-1}\right. \\
\text { of soil DW) }\end{array}$ & $\begin{array}{l}\text { 95\% Confidence } \\
\text { intervals }\end{array}$ & $\begin{array}{l}\mathrm{EC}_{50}\left(\mathrm{mg} \mathrm{kg}^{-1} \text { of }\right. \\
\text { soil DW) }\end{array}$ & $\begin{array}{l}95 \% \text { Confidence } \\
\text { intervals }\end{array}$ & $\begin{array}{l}\mathrm{EC}_{50}\left(\mathrm{mg} \mathrm{kg}^{-1}\right. \\
\text { of soil DW) }\end{array}$ & $\begin{array}{l}95 \% \text { Confidence } \\
\text { intervals }\end{array}$ \\
\hline \multicolumn{7}{|l|}{ Spring barley } \\
\hline Root length & 88.97 & $71.24-111.10$ & 114.9 & $74.64-177.00$ & 97.78 & $69.63-137.30$ \\
\hline Shoot length & 10.16 & $7.96-12.98$ & 19.86 & $14.14-27.88$ & 14.49 & $12.08-19.87$ \\
\hline Fresh weight & 10.04 & $7.55-11.67$ & 11.40 & $8.66-16.68$ & 10.31 & $9.01-12.10$ \\
\hline \multicolumn{7}{|l|}{ Common radish } \\
\hline Root length & 137.20 & $72.07-156.10$ & 120.40 & $28.64-255.80$ & 101.40 & $67.41-152.70$ \\
\hline Shoot length & 228.50 & $102.80-387.20$ & 149.60 & $35.51-300.60$ & 90.87 & $50.92-162.10$ \\
\hline Fresh weight & 172.00 & $84.83-248.70$ & 115.20 & $79.07-168.00$ & 129.60 & $82.20-204.20$ \\
\hline
\end{tabular}

exhibited phytotoxic effect. This is demonstrated by the decrease of seedlings' fresh weight yield, decrease of the length of their shoots and roots, and the calculated $\mathrm{EC}_{50}$ values on the basis of inhibition of these toxicity biomarkers (Fig. 2, Table 1).

The observed phytotoxicity was significantly influenced by ILs' concentrations. This is confirmed by the reports of other authors, who also point out to the strict dependency of the level of phytotoxicity on the used ILs' concentration. Numerous papers (Biczak et al. 2010, 2013, 2014a, 2015; Cvjetko Bubalo et al. 2014a; Liu et al. 2013, 2014, 2015a, b; Biczak 2016; Pawłowska and Biczak 2016; Wang et al. 2009) demonstrate the linear relationship between phytotoxicity of quaternary ammonium salts (QASs) and ILs and the concentration of the compound in soil. Such strong correlations are observed mainly for the high concentrations of these chemicals, whereas ILs used in low concentrations may have a stimulatory effect on the growth and development of plants (Liu et al. 2013, 2015b, 2016b).

Spring barley was very sensitive to the used ILs, and the plant material could only be obtained in the case of ILs' concentrations of 1 and $10 \mathrm{mg} \mathrm{kg}^{-1}$ of the soil DW. Common radish exhibited higher resistance to the tested ILs (Fig. 2, Table 1). The difference in the sensitivity of spring barley and common radish observed in the present study may stem from the reaction of the root systems of these plants to the tested salts. At higher IL concentrations (50-1000 $\mathrm{mg} \mathrm{kg}^{-1}$ of soil DW), over $90 \%$ spring barley root growth inhibition was observed, which effectively disabled the plants to absorb and transport water and nutrients. As reported by Chapman et al. (2012), proper root development determined the optimum growth and development of each plant. Such root inhibition was not observed for common radish.

It is shown that there is no significant effect of cation structures on the phytotoxicity of the tested ILs to spring barley and common radish. The results of shoot length, root length, fresh weight, and $\mathrm{EC}_{50}$ values of both plants showed no remarkable differences (Fig. 2, Table 1). This is further illustrated by the photographs of the seedlings cultivated on the soil with increasing ILs' concentration, presented in Supplementary Materials (Suppl.Figs 1 and 2). Currently, the obtained results cannot be compared to the other studies describing the IL effect on terrestrial plants. Only Pham et al. (2016) compared the effect of pyridinium, pyrolidinium, and imidazolium bromides on the growth of the $P$. subcapitata algae and stated that the IL with the pyridinium cation was more toxic to the algae than the other compounds. Cho et al. (2008) evaluated toxicity of imidazolium, pyridinium, pyrrolidinium, phosphonium, and ammonium ILs on the algae, Selenastrum capricornutum, and the obtained results showed that the pyrrolidinium cation was the least toxic. However, Stolte et al. (2007) proved higher toxicity of ILs containing aromatic cation for duckweed (Lemma minor) and microorganisms. The study carried out by Couling et al. (2006) pointed at the fact that the higher amount of nitrogen atoms in a cation ring caused the higher toxicity of ionic liquids for aquatic organisms. However, these studies were conducted in an aquatic environment, whereas our study was conducted in the soil, which is a very complex environment for toxicity study. The obtained results can be influenced by numerous factors, such as $\mathrm{pH}$ of the soil, content of humus substances, soil colloids, and sorption level (Cvjetko Bubalo et al. 2014b; Matzke et al. 2008a, 2009; Mrozik et al. 2009; Studzińska et al. 2009).

Moreover, the present study determined the influence of ILs with different cation on the dry weight content in spring barley seedlings and common radish leaves. In both plants, an increase of dry weight was observed, correlated to the increase of ILs' concentration in the soil (Table 2).

High ionic liquid concentrations lead to soil salinity, which, in turn, disturbs the water metabolism in plants, leading to the observed increased level of dry weight in both experimental plants. Biczak et al. (2013, 2014a, 2015, 2016b), Biczak (2016), Matusiak et al. (2013), and Pawłowska and Biczak (2016) came to analogous conclusions in their studies on the 
Table 2 Effect of ILs on the dry weight $\left(\mathrm{g} \mathrm{g}^{-1} \mathrm{FW}\right)$ in spring barley seedlings and common radish leaves

\begin{tabular}{llll} 
Dry weight content $\left(\mathrm{g} \mathrm{g}^{-1} \mathrm{FW}\right)$ in spring barley seedlings and common radish leaves & \\
\hline IL concentration $\left(\mathrm{mg} \mathrm{kg}^{-1}\right.$ of soil DW) & {$[$ Pyrrol $]\left[\mathrm{PF}_{6}\right]$} & {$[$ Piper $]\left[\mathrm{PF}_{6}\right]$} & {$[$ Pyrid $]\left[\mathrm{PF}_{6}\right]$} \\
\hline Spring barley & & & \\
0 & $0.0787 \pm 0.0013 \mathrm{c}$ & $0.0757 \pm 0.0032 \mathrm{c}$ & $0.0763 \pm 0.0014 \mathrm{c}$ \\
1 & $0.0793 \pm 0.0041 \mathrm{c}$ & $0.0762 \pm 0.0019 \mathrm{c}$ & $0.0760 \pm 0.0008 \mathrm{c}$ \\
10 & $0.1047 \pm 0.0049 \mathrm{a}$ & $0.0868 \pm 0.0020 \mathrm{ba}$ & $0.0971 \pm 0.0105 \mathrm{ab}$ \\
50 & - & - & - \\
100 & - & - & - \\
400 & - & - & - \\
700 & - & - & - \\
1000 & - & - & - \\
Common radish & & & \\
0 & $0.0609 \pm 0.0025 \mathrm{ijkl}$ & $0.0668 \pm 0.0122 \mathrm{hijk}$ & $0.0508 \pm 0.0005 \mathrm{kl}$ \\
1 & $0.0533 \pm 0.0017 \mathrm{kl}$ & $0.0594 \pm 0.0043 \mathrm{jkl}$ & $0.0494 \pm 0.00181$ \\
10 & $0.0622 \pm 0.0041 \mathrm{ijkl}$ & $0.0594 \pm 0.0047 \mathrm{jkl}$ & $0.0541 \pm 0.0024 \mathrm{kl}$ \\
50 & $0.0765 \pm 0.0064 \mathrm{hc}$ & $0.0720 \pm 0.0010 \mathrm{hc}$ & $0.0719 \pm 0.0057 \mathrm{hij}$ \\
100 & $0.0952 \pm 0.0090 \mathrm{~g}$ & $0.0766 \pm 0.0040 \mathrm{~g}$ & $0.0804 \pm 0.0057 \mathrm{gh}$ \\
400 & $0.1786 \pm 0.0033 \mathrm{f}$ & $0.1748 \pm 0.0130 \mathrm{f}$ & $0.2052 \pm 0.0037 \mathrm{dc}$ \\
700 & $0.2444 \pm 0.0010 \mathrm{c}$ & $0.2045 \pm 0.0066 \mathrm{c}$ & $0.2209 \pm 0.0051 \mathrm{~d}$ \\
1000 & $0.2596 \pm 0.0045 \mathrm{bc}$ & $0.2878 \pm 0.0012 \mathrm{a}$ & $0.2675 \pm 0.0101 \mathrm{~b}$ \\
\hline
\end{tabular}

Data are expressed as a mean \pm SD of three replicates for each concentration. Values denoted by the same letters in the columns do not differ statistically at $p<0.05$ determination of toxicity of different chemicals for terrestrial plants.

Table 3 Effect of ILs on the fluoride $\left(\mathrm{mg} \mathrm{kg}^{-1} \mathrm{DW}\right)$ content in spring barley seedlings and common radish leaves
Increase in the concentration of $[\mathrm{Pyrrol}]\left[\mathrm{PF}_{6}\right],[\mathrm{Piper}]\left[\mathrm{PF}_{6}\right]$, and $[\mathrm{Piryd}]\left[\mathrm{PF}_{6}\right]$ in the soil led to a systematic decrease of GP

\begin{tabular}{llll}
\hline The fluoride content $\left(\mathrm{mg} \mathrm{kg}^{-1} \mathrm{FW}\right)$ in spring barley seedlings and common radish leaves & \\
\hline IL concentration $\left(\mathrm{mg} \mathrm{kg}^{-1}\right.$ of soil DW) & {$[$ Pyrrol $]\left[\mathrm{PF}_{6}\right]$} & {$[$ Piper $]\left[\mathrm{PF}_{6}\right]$} & {$[$ Pyrid $]\left[\mathrm{PF}_{6}\right]$} \\
\hline Spring barley & & & \\
0 & $4.306 \pm 0.120 \mathrm{a}$ & $4.338 \pm 0.037 \mathrm{a}$ & $4.279 \pm 0.228 \mathrm{a}$ \\
1 & $4.359 \pm 0.170 \mathrm{a}$ & $4.369 \pm 0.076 \mathrm{a}$ & $4.351 \pm 0.151 \mathrm{a}$ \\
10 & $4.287 \pm 0.090 \mathrm{a}$ & $4.396 \pm 0.220 \mathrm{a}$ & $4.477 \pm 0.175 \mathrm{a}$ \\
50 & - & - & - \\
100 & - & - & - \\
400 & - & - & - \\
700 & - & - & - \\
1000 & - & - & - \\
Common radish & & & \\
0 & $2.094 \pm 0.130 \mathrm{~g}$ & $2.073 \pm 0.052 \mathrm{~g}$ & $2.109 \pm 0.090 \mathrm{f}$ \\
1 & $2.132 \pm 0.158 \mathrm{~g}$ & $2.102 \pm 0.100 \mathrm{~g}$ & $2.279 \pm 0.165 \mathrm{f}$ \\
10 & $2.699 \pm 0.306 \mathrm{fg}$ & $3.274 \pm 0.240 \mathrm{f}$ & $2.731 \pm 0.077 \mathrm{fg}$ \\
50 & $5.253 \pm 0.207 \mathrm{e}$ & $5.863 \pm 0.126 \mathrm{e}$ & $5.140 \pm 0.129 \mathrm{e}$ \\
100 & $7.671 \pm 0.211 \mathrm{~d}$ & $8.010 \pm 0.144 \mathrm{~d}$ & $7.616 \pm 0.012 \mathrm{~d}$ \\
400 & $9.510 \pm 0.179 \mathrm{c}$ & $9.805 \pm 0.452 \mathrm{c}$ & $9.218 \pm 0.096 \mathrm{c}$ \\
700 & $12.106 \pm 0.172 \mathrm{~b}$ & $12.298 \pm 0.678 \mathrm{~b}$ & $12.104 \pm 0.198 \mathrm{~b}$ \\
1000 & $14.386 \pm 0.318 \mathrm{a}$ & $15.103 \pm 0.396 \mathrm{a}$ & $14.584 \pm 0.256 \mathrm{a}$ \\
\hline
\end{tabular}

Data are expressed as a mean \pm SD of three replicates for each concentration. Values denoted by the same letters in the columns do not differ statistically at $p<0.05$ 
Table 4 Effect of ILs on photosynthetic pigment content ( $\left.\mathrm{mg} \mathrm{g}^{-1} \mathrm{DW}\right)$ in spring barley seedlings and common radish leaves

Concentration of ILs Pigments $\left(\mathrm{mg} \mathrm{g}^{-1} \mathrm{DW}\right)$

(mg kg${ }^{-1}$ of soil DW)

Chla Chl $\quad$ C

Chlb Car

Spring barley

[Pyrrol] $\left[\mathrm{PF}_{6}\right] \quad 0$

$13.196 \pm 0.341 \mathrm{de} \quad 3.520 \pm 0.042 \mathrm{c}$

$1 \quad 13.923 \pm 0.665 \mathrm{bcd} \quad 3.498 \pm 0.194 \mathrm{c}$

$10 \quad 10.374 \pm 0.157 \mathrm{f} \quad 2.684 \pm 0.005 \mathrm{e}$

$50 \quad-$

$100-$

$400 \quad-$

$700 \quad-$

$1000 \quad-$

$\begin{array}{lll}{[\text { Piper }]\left[\mathrm{PF}_{6}\right]} & 0 & 15.092 \pm 0.110 \mathrm{a} \\ & 1 & 14.381 \pm 0.017 \mathrm{~b} \\ 10 & 13.522 \pm 0.283 \mathrm{~cd} \\ 50 & - \\ 100 & - \\ & 400 & - \\ & 700 & - \\ & 1000 & - \\ {[\text { Pyrid }]\left[\mathrm{PF}_{6}\right]} & 0 & 15.420 \pm 0.094 \mathrm{a} \\ & 1 & 14.018 \pm 0.151 \mathrm{bc} \\ 10 & 12.547 \pm 0.102 \mathrm{e} \\ 50 & - \\ 100 & - \\ 400 & - \\ 700 & - \\ 1000 & -\end{array}$

Common radish

[Pyrrol] $\left[\mathrm{PF}_{6}\right]$

$\begin{array}{ll}1 & 9.012 \pm 0.294 \mathrm{def} \\ 10 & 8.702 \pm 0.029 \mathrm{fg}\end{array}$

$50 \quad 7.521 \pm 0.027 \mathrm{i}$

$100 \quad 7.665 \pm 0.120 \mathrm{i}$

$400 \quad 5.051 \pm 0.119 \mathrm{j}$

$700 \quad 2.187 \pm 0.145 \mathrm{~m}$

$1000 \quad 1.737 \pm 0.068$ no

[Piper] $\left[\mathrm{PF}_{6}\right]$

0

$10.069 \pm 0.039 \mathrm{c}$

$1 \quad 10.589 \pm 0.260 \mathrm{~b}$

$10 \quad 10.174 \pm 0.028 \mathrm{c}$

$50 \quad 9.253 \pm 0.079 \mathrm{de}$

$100 \quad 8.908 \pm 0.152 \mathrm{ef}$

$400 \quad 4.850 \pm 0.209 \mathrm{j}$

$700 \quad 3.909 \pm 0.079 \mathrm{k}$

$1000 \quad 2.064 \pm 0.027 \mathrm{mn}$

[Pyrid] $\left[\mathrm{PF}_{6}\right]$

0

$11.601 \pm 0.113 \mathrm{a}$

$1 \quad 10.893 \pm 0.083 b$

$10 \quad 9.337 \pm 0.018 \mathrm{~d}$

$50 \quad 8.313 \pm 0.022 \mathrm{gh}$

$100 \quad 8.222 \pm 0.222 \mathrm{~h}$

$1.598 \pm 0.047 \mathrm{~h}$

$0.595 \pm 0.078 \mathrm{i}$

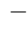

$-$

$-$

$-$

$-$

$3.989 \pm 0.051 \mathrm{a}$

$3.847 \pm 0.013 \mathrm{ab}$

$3.626 \pm 0.051 b c$

$-$$$
-
$$$$
-
$$

$4.055 \pm 0.014 \mathrm{a}$

$3.654 \pm 0.083 b c$

$3.116 \pm 0.051 \mathrm{~d}$

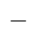

$-$

$-$

$-$

$-$

$4.001 \pm 0.027 \mathrm{ab}$

$3.118 \pm 0.093 \mathrm{de}$

$2.773 \pm 0.031 \mathrm{fg}$

$2.570 \pm 0.092 \mathrm{~g}$

$2.642 \pm 0.030 \mathrm{~g}$

$0.401 \pm 0.026 \mathrm{j}$

$3.193 \pm 0.081 \mathrm{a}$

$2.374 \pm 0.128 \mathrm{cde}$

$2.338 \pm 0.013 \mathrm{def}$

$2.011 \pm 0.163 \mathrm{fg}$

$1.934 \pm 0.015 \mathrm{~g}$

$1.302 \pm 0.030 \mathrm{~h}$

$0.641 \pm 0.025 \mathrm{jk}$

$3.282 \pm 0.029 \mathrm{cde} \quad 2.591 \pm 0.016 \mathrm{~cd}$

$3.502 \pm 0.058 \mathrm{c} \quad 2.716 \pm 0.068 \mathrm{bc}$

$3.335 \pm 0.011 \mathrm{~cd} \quad 2.613 \pm 0.005 \mathrm{~cd}$

$2.600 \pm 0.016 \mathrm{a}$

$2.550 \pm 0.003 \mathrm{~g}$

$1.170 \pm 0.044 \mathrm{i}$

$0.929 \pm 0.019 \mathrm{i}$

$0.330 \pm 0.088 \mathrm{j}$

$4.140 \pm 0.149 \mathrm{a}$

$3.813 \pm 0.121 b$

$3.121 \pm 0.155 \mathrm{de}$

$3.018 \pm 0.256 \mathrm{ef}$

$2.778 \pm 0.071 \mathrm{fg}$
$2.147 \pm 0.004 \mathrm{efg}$

$2.172 \pm 0.037 \mathrm{efg}$

$1.243 \pm 0.049 \mathrm{hi}$

$1.056 \pm 0.022 \mathrm{hi}$

$0.626 \pm 0.079 \mathrm{jk}$

$3.161 \pm 0.066 \mathrm{a}$

$3.013 \pm 0.075 \mathrm{ab}$

$2.480 \pm 0.078 \mathrm{cde}$

$2.267 \pm 0.460 \mathrm{defg}$

$1.943 \pm 0.025 \mathrm{~g}$
Chl $a+\mathrm{Chl} b$

$\mathrm{Chl} a / \mathrm{Chl} b$

$\mathrm{Chl}(a+b) / \mathrm{Car}$

$\begin{array}{ll}16.716 \pm 0.377 \mathrm{~d} & 3.749 \pm 0.064 \mathrm{a} \\ 17.420 \pm 0.512 \mathrm{~cd} & 3.995 \pm 0.409 \mathrm{a} \\ 13.058 \pm 0.156 \mathrm{f} & 3.865 \pm 0.059 \mathrm{a} \\ - & - \\ - & - \\ - & - \\ - & - \\ - & - \\ 19.201 \pm 0.147 \mathrm{a} & 3.814 \pm 0.038 \mathrm{a} \\ 18.228 \pm 0.027 \mathrm{~b} & 3.738 \pm 0.010 \mathrm{a} \\ 17.148 \pm 0.329 \mathrm{~cd} & 3.729 \pm 0.038 \mathrm{a}\end{array}$

$5.242 \pm 0.024 \mathrm{~b}$

$4.998 \pm 0.025 \mathrm{e}$

$5.086 \pm 0.009 \mathrm{cdc}$

$-$

$-$

$-$

$-$

$-$

$5.548 \pm 0.025 \mathrm{a}$

$5.264 \pm 0.015 b$

$5.205 \pm 0.018 \mathrm{bc}$

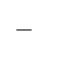

$-$

$19.476 \pm 0.082 \mathrm{a} \quad 3.803 \pm 0.035 \mathrm{a}$

$\begin{array}{ll}17.672 \pm 0.223 \mathrm{bc} & 3.837 \pm 0.060 \mathrm{a} \\ 15.663 \pm 0.124 \mathrm{e} & 4.027 \pm 0.067 \mathrm{a}\end{array}$

$15.663 \pm 0.124 \mathrm{e}$

4.02

$-$

$-$

$-$

$-$

$15.732 \pm 0.090 \mathrm{a} \quad 2.932 \pm 0.010 \mathrm{def}$

$4.930 \pm 0.151$ abcde

$12.130 \pm 0.385 \mathrm{ef} \quad 2.890 \pm 0.021 \mathrm{ef}$

$11.475 \pm 0.047 \mathrm{gh}$

$10.091 \pm 0.108 \mathrm{i}$

$3.139 \pm 0.033 \mathrm{cdef}$

$2.929 \pm 0.102 \mathrm{def}$

$5.116 \pm 0.180 \mathrm{abcde}$

$4.909 \pm 0.032 \mathrm{abcdef}$

$10.308 \pm 0.094 \mathrm{i}$

$2.902 \pm 0.076 \mathrm{ef}$

$5.038 \pm 0.384$ abcde

$6.648 \pm 0.164 j$

$3.162 \pm 0.033 \mathrm{cdef}$

$5.331 \pm 0.066 \mathrm{abc}$

$2.782 \pm 0.067 \mathrm{~m}$

$3.745 \pm 0.192 b c d e f$

$5.106 \pm 0.060 \mathrm{abcde}$

$2.137 \pm 0.045 \mathrm{no}$

$4.356 \pm 0.462 \mathrm{bcd}$

$4.343 \pm 0.270 \mathrm{efg}$

$13.351 \pm 0.062 \mathrm{~d}$

$3.068 \pm 0.022 \mathrm{cdef}$

$4.096 \pm 0.120 \mathrm{fg}$

$14.091 \pm 0.317 \mathrm{c}$

$3.033 \pm 0.026 \mathrm{cdef}$

$5.153 \pm 0.019$ abcde

$13.508 \pm 0.017 \mathrm{~d}$

$3.051 \pm 0.019 \mathrm{cdef}$

$5.188 \pm 0.016$ abcde

$11.854 \pm 0.064 \mathrm{fg}$

$3.559 \pm 0.052 \mathrm{bcdef}$

$5.171 \pm 0.009$ abcde

$11.458 \pm 0.155 \mathrm{gh}$

$6.020 \pm 0.253 \mathrm{k}$

$3.493 \pm 0.055$ bcdef

$5.520 \pm 0.023 \mathrm{ab}$

$4.838 \pm 0.0961$

$4.145 \pm 0.025 \mathrm{bcdef}$

$5.276 \pm 0.029 \mathrm{abcd}$

$2.394 \pm 0.075 \mathrm{mno}$

$4.208 \pm 0.048 \mathrm{bcde}$

$4.842 \pm 0.013 \mathrm{abcdef}$

$15.741 \pm 0.258 \mathrm{a}$

$6.589 \pm 0.922 \mathrm{a}$

$14.705 \pm 0.168 \mathrm{~b}$

$2.804 \pm 0.075 \mathrm{ef}$

$4.581 \pm 0.013 \mathrm{cdefg}$

$12.459 \pm 0.167 \mathrm{e}$

$2.859 \pm 0.077 \mathrm{ef}$

$3.871 \pm 0.537 \mathrm{~g}$

$4.982 \pm 0.183$ abcde

$11.331 \pm 0.263 \mathrm{gh}$

$2.996 \pm 0.142 \mathrm{cdef}$

$4.882 \pm 0.140 \mathrm{abcde}$

$11.001 \pm 0.217 \mathrm{~h}$

$2.768 \pm 0.233 \mathrm{f}$

$5.028 \pm 0.229 \mathrm{abcde}$

$5.113 \pm 0.849$ abcde

$5.663 \pm 0.163 \mathrm{a}$ 
Table 4 (continued)

Concentration of ILs Pigments ( $\left.\mathrm{mg} \mathrm{g}^{-1} \mathrm{DW}\right)$

$\left(\mathrm{mg} \mathrm{kg}^{-1}\right.$ of soil DW)

Chis

\begin{tabular}{rllllll}
\hline & Chla & Chl $b$ & Car & Chl $a+$ Chl $b$ & Chla/Chl $b$ & Chl $(a+b) /$ Car \\
\hline 400 & $3.330 \pm 0.1261$ & $0.989 \pm 0.054 \mathrm{i}$ & $0.913 \pm 0.056 \mathrm{ij}$ & $4.319 \pm 0.1801$ & $3.369 \pm 0.059 \mathrm{bcdef}$ & $4.747 \pm 0.399 \mathrm{bcdef}$ \\
700 & $2.139 \pm 0.050 \mathrm{~m}$ & $0.489 \pm 0.047 \mathrm{j}$ & $0.548 \pm 0.013 \mathrm{jk}$ & $2.629 \pm 0.003 \mathrm{mn}$ & $4.403 \pm 0.500 \mathrm{bc}$ & $4.504 \pm 0.095 \mathrm{cdefg}$ \\
1000 & $1.612 \pm 0.021 \mathrm{o}$ & $0.336 \pm 0.008 \mathrm{j}$ & $0.441 \pm 0.048 \mathrm{k}$ & $1.948 \pm 0.015 \mathrm{o}$ & $4.796 \pm 0.177 \mathrm{~b}$ & $4.452 \pm 0.491 \mathrm{defg}$ \\
\hline
\end{tabular}

Data are expressed as a mean \pm SD of three replicates for each concentration. Values denoted by the same letters in the columns do not differ statistically at $p<0.05$

and GR values of spring barley seeds. In the case of common radish grown on the soil with the addition of ILs, a small decrease in the germination potential and germination rate of this plant seeds was noted, especially after the application of the highest concentrations of [Pyrrol] $\left[\mathrm{PF}_{6}\right]$ (Suppl.Table 1). Liu et al. (2014) described a similar decrease in germination capacity of wheat and spring barley seeds under the influence of imidazolium ILs.

\section{Effect of ILs on fluoride content}

In the discussed studies, the content of fluoride ions in seedlings of spring barley and radish leaves was determined (Table 3).

Common radish accumulated large amounts of fluoride ions in its leaves, and the observed increase in the level of these anions was directly proportional to the increase in concentration of all ILs in the soil. In case of application of all studied ILs in a dosage of $1000 \mathrm{mg} \mathrm{kg}^{-1}$ of soil DW, the amount of fluoride in plants was approximately seven times higher than in the control groups. Such changes were not established for spring barley, probably because the analyses were possible to conduct only for the objects with the concentration of $10 \mathrm{mg}$ ILs per $1 \mathrm{~kg}$ of soil DW. The effect of toxic fluoride on plants is visible in the form of chlorosis, peripheral necrosis, leaf distortion and malformation, and abnormal fruit development (Pandey et al. 2014). Telesiński and Śnioszek (2009) determined that fluorine has a negative influence on the assimilation and photosynthesis processes in plants. These phenomena stem from the destructive influence of $\mathrm{F}^{-}$on chloroplasts.

\section{Effect of ILs on pigment content}

An analysis of the results on the effect of ILs on photosynthetic pigments' level in spring barley seedlings and common radish leaves demonstrates the inhibitory influence of these salts on the level of chlorophylls and carotenoids. All the ILs used in the experiment led to a systematic decrease in the content of photosynthetic pigments in both plants, which was correlated to the increase of these substances in the soil (Table 4).
A similar decrease in the photosynthetic pigment content in spring barley and wheat seedlings and radish and broad bean leaves, duckweed, and algae under IL influence was also observed by Cvjetko Bubalo et al. (2014a), Biczak (2016), Biczak et al. (2016a), Pawłowska and Biczak (2016), Wang et al. (2009), Liu et al. (2014), Zhang et al. (2013), and Ma et al. (2010). The cited authors demonstrate that the presence of ILs in the environment generates a high level of oxidative stress in plants, which is linked to the elevated reactive oxygen species (ROS) production (Anjaneyulu et al. 2014; Di Baccio et al. 2014; Oukarroum et al. 2015). Some authors (Cvjetko Bubalo et al. 2014a; Biczak 2016; Biczak et al. 2016a, b) also report that chlorophyll content constitutes the most important biomarker of oxidative stress because its changes are directly correlated with the inhibition of the growth and yield of plants. Islam et al. (2014) and Herman et al. (1998) believe that chlorophyll level reflects the health of plant leaves.

Besides the content of photosynthetic pigments, the following indexes are also used to evaluate the physiological changes: $\mathrm{Chl} a / \mathrm{Chl} b$ ratio and $\mathrm{Chl}(a+b) / \mathrm{Car}$ ratio. The increase of Chla/ $\mathrm{Chl} b$ value and decrease of $\operatorname{Chl}(a+b) / \mathrm{Car}$ value indicate the occurrence of oxidative stress in plants (Arias-Baldrich et al. 2015; Chen et al. 2014). In addition, the decrease of Chl $(a+b)$ / Car value indicates antioxidant defense of the plant organism, by increasing carotenoid content. Carotenoids are efficient ROS scavengers, thus protecting PSI and PSII photosystems (Arias-Baldrich et al. 2015; Wang et al. 2009; Chen et al. 2014; Gengmao et al. 2015). No statistically significant differences in the values of both mentioned indexes were determined in the spring barley seedlings. In the case of common radish, value of the Chla/Chl $b$ index increased on the samples with the highest ILs' concentration; additionally, for the same samples, a decrease of the $\mathrm{Chl}(a+b) / \mathrm{Car}$ value was observed in comparison with the control (Table 4). This indicates oxidative stress in radish leaves and suggests the attempt of antioxidant defense carried out by the plant.

\section{Effect of ILs on MDA and $\mathrm{H}_{2} \mathrm{O}_{2}$ content}

The peroxidation level of protein-lipid membranes in plant organisms is commonly determined on the basis of 

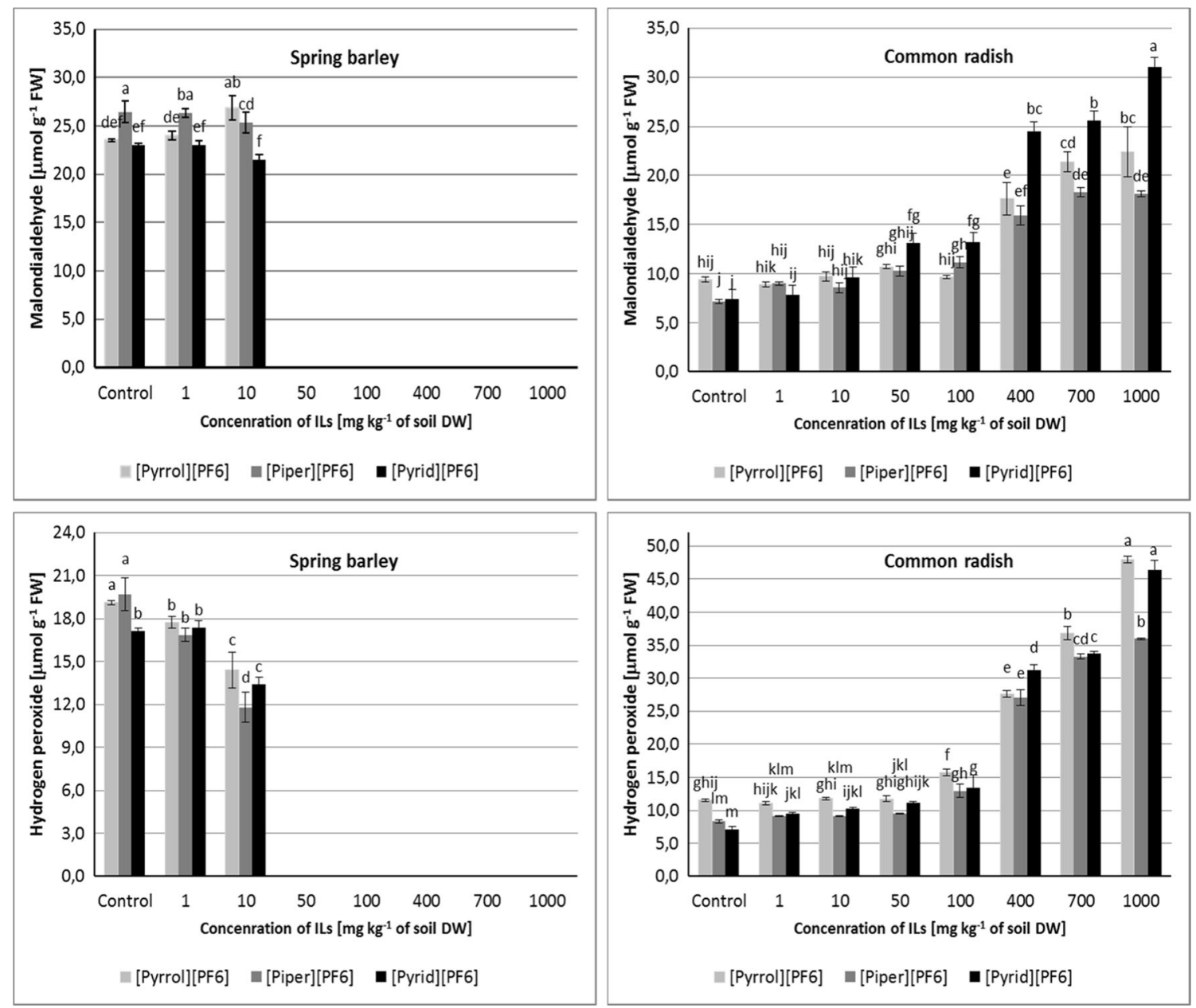

Fig. 3 Effect of ILs on MDA ( $\left.\mu \mathrm{mol} \mathrm{g}{ }^{-1} \mathrm{FW}\right)$ and $\mathrm{H}_{2} \mathrm{O}_{2}\left(\mu \mathrm{mol} \mathrm{g}^{-1} \mathrm{FW}\right)$ content in spring barley seedlings and common radish leaves. Data are expressed as a mean \pm SD of three replicates for each concentration. Values denoted by the same letters for each ILs do not differ statistically at $p<0.05$

malondialdehyde content. Thus, the MDA content is one of the most important indices, always determined in the study of oxidative stress level in plants subjected to the influence of different stress factors (Liu et al. 2013, 2014; Rosalie et al. 2015; Radošević et al. 2015). In the present paper, no considerable changes of MDA content of spring barley seedlings were observed between controls and samples cultivated on the soil with the addition of ILs. However, a significant increase of MDA content in the common radish leaves, which at the highest IL concentrations averaged 250-400\% in comparison to the control, was observed (Fig. 3). The greatest changes of MDA level were caused by the ionic liquid containing the aromatic cation [Pyrid] $\left[\mathrm{PF}_{6}\right]$.

In the available literature, studies can be found describing the effect of ILs on the biochemical and physiological changes in plants, reporting increase of MDA content in plant cells (Cvjetko Bubalo et al. 2014a; Liu et al. 2013, 2014, 2015a, 2016a, b; Biczak et al. 2016a). The authors explain that the observed tendencies in the changes of MDA level were caused by oxidative stress generated by high concentrations of ILs.
Another biomarker indicating oxidative stress in plants is the $\mathrm{H}_{2} \mathrm{O}_{2}$ accumulation in their cells. Hydrogen peroxide is the most stable chemical molecule of all ROS, characterized by the capability for a rapid penetration of cellular membranes. The increase of $\mathrm{H}_{2} \mathrm{O}_{2}$ content in plant cells is observed in the conditions of intensified superoxide anion radical detoxification and in the situation when enzymatic mechanisms of $\mathrm{H}_{2} \mathrm{O}_{2}$ detoxification fail in plants (Liu et al. 2013, 2015b; Sánchez-Rodríguez et al. 2010; Kumar et al. 2013; Demidchik 2015). Zhang et al. (2013), Liu et al. (2014), and Biczak (2016) found that $\mathrm{H}_{2} \mathrm{O}_{2}$ accumulation depends on the ILs' concentration in the environment of plant vegetation.

The results revealed that extremely high accumulation of $\mathrm{H}_{2} \mathrm{O}_{2}$ was found in common radish cells, and the observed increase was positively correlated with the concentration of the used ionic liquid. The highest increase in the level of hydrogen peroxide was observed when high concentrations of [Pyrrol] $\left[\mathrm{PF}_{6}\right]$ and [Pyrid] $\left[\mathrm{PF}_{6}\right]$ were used (Fig. 3). On the contrary, $\mathrm{H}_{2} \mathrm{O}_{2}$ content in spring barley seedlings was decreased, which was the result of elevated activity of the 
Table 5 Enzymatic activities of SOD $\left(\mathrm{U} \mathrm{mg}^{-1}\right.$ protein), CAT $\left(\mathrm{U} \mathrm{mg}^{-1}\right.$ protein $\left.\mathrm{min}^{-1}\right)$, and POD $\left(\mathrm{U} \mathrm{mg}^{-1} \mathrm{protein} \mathrm{min}^{-1}\right)$ in spring barley seedlings and common radish leaves treated with ILs

Concentration of ILs (mg kg-1 of soil DW)

The activity of enzymes

\begin{tabular}{lll}
\hline $\begin{array}{l}\text { Superoxide dismutase } \\
\left(\mathrm{U} \mathrm{mg} \mathrm{m}^{-1} \text { protein }\right)\end{array}$ & $\begin{array}{l}\text { Catalase } \\
\left(\mathrm{U} \mathrm{mg}^{-1} \text { protein } \mathrm{min}^{-1}\right)\end{array}$ & $\begin{array}{l}\text { Peroxidase } \\
\left(\mathrm{U} \mathrm{mg}^{-1} \text { protein } \mathrm{min}^{-1}\right)\end{array}$
\end{tabular}

Spring barley

[Pyrrol][PF $]$

Common radish

[Pyrrol] $\left[\mathrm{PF}_{6}\right]$

[Piper $]\left[\mathrm{PF}_{6}\right]$

[Pyrid] $\left[\mathrm{PF}_{6}\right]$

$$
\begin{aligned}
& 9.901 \pm 0.943 \mathrm{bc} \\
& 10.113 \pm 0.168 \mathrm{abc} \\
& 8.950 \pm 0.411 \mathrm{c} \\
& - \\
& - \\
& -
\end{aligned}
$$

$11.223 \pm 0.998 \mathrm{ab}$

$11.769 \pm 0.213 \mathrm{a}$

$11.781 \pm 0.280 \mathrm{a}$

$-$

100

400

700

1000

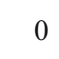

1

10

50

100

400

700

1000

$\begin{array}{rrl}{[\text { Pyrrol }]\left[\mathrm{PF}_{6}\right]} & 0 & 10.915 \pm 0.085 \mathrm{ghijk} \\ 1 & 11.415 \pm 0.712 \mathrm{fghij} \\ 10 & 10.823 \pm 0.455 \mathrm{ghijk} \\ 50 & 10.579 \pm 0.207 \mathrm{hijk} \\ 100 & 10.501 \pm 0.398 \mathrm{ijk} \\ 400 & 19.271 \pm 0.384 \mathrm{bc} \\ 700 & 17.931 \pm 0.647 \mathrm{cde} \\ {[\text { Piper }]\left[\mathrm{PF}_{6}\right]} & 1000 & 17.734 \pm 0.175 \mathrm{de} \\ & 0 & 12.197 \pm 0.612 \mathrm{fg} \\ & 1 & 11.953 \pm 0.379 \mathrm{fgh} \\ & 10 & 12.698 \pm 0.490 \mathrm{f} \\ 50 & 12.340 \pm 0.068 \mathrm{f} \\ {[\text { Pyrid }]\left[\mathrm{PF}_{6}\right]} & 100 & 12.548 \pm 0.165 \mathrm{f} \\ & 400 & 22.380 \pm 0.574 \mathrm{a} \\ & 700 & 19.489 \pm 0.800 \mathrm{~b} \\ & 1000 & 18.654 \pm 0.496 \mathrm{bcd} \\ 0 & 10.058 \pm 0.263 \mathrm{jk} \\ 10 & 11.722 \pm 0.721 \mathrm{fghi} \\ & 10.011 \pm 0.050 \mathrm{jk}\end{array}$

$9.103 \pm 0.225 \mathrm{c}$

$\begin{array}{ll}0.0483 \pm 0.0014 \mathrm{~cd} & 1 \\ 0.0458 \pm 0.0005 \mathrm{c} & 16.8 \\ 0.0591 \pm 0.0020 \mathrm{a} & 38.6 \\ - & - \\ - & - \\ - & - \\ - & -\end{array}$

$0.0434 \pm 0.0014 \mathrm{ef}$

$0.0448 \pm 0.0014 \mathrm{de}$

$9.897 \pm 0.360 \mathrm{ef}$

$12.215 \pm 0.175 \mathrm{de}$

$26.976 \pm 0.411 \mathrm{~b}$

$0.0519 \pm 0.0025 b$

$-$

$-$

$-$

$-$

$-$

$6.424 \pm 0.100 \mathrm{~g}$

$8.074 \pm 0.288 \mathrm{fg}$

$13.118 \pm 0.454 \mathrm{~d}$

$0.0286 \pm 0.0016 \mathrm{e}$

$0.0293 \pm 0.0016 \mathrm{e}$

$0.0448 \pm 0.0013 \mathrm{~cd}$

$-$

$-$

$-$

-

$-$

$\begin{array}{ll}0.0255 \pm 0.0014 \mathrm{efghi} & 0.897 \pm 0.019 \mathrm{kl} \\ 0.0244 \pm 0.001 \mathrm{bghi} & 0.827 \pm 0.085 \mathrm{kl} \\ 0.0231 \pm 0.0026 \mathrm{ij} & 0.895 \pm 0.005 \mathrm{kl} \\ 0.0281 \pm 0.0023 \mathrm{defgh} & 2.409 \pm 0.056 \mathrm{hi} \\ 0.0320 \pm 0.0306 \mathrm{~cd} & 2.739 \pm 0.177 \mathrm{gh} \\ 0.0370 \pm 0.0009 \mathrm{~b} & 9.510 \pm 0.227 \mathrm{de} \\ 0.0334 \pm 0.0008 \mathrm{bc} & 9.901 \pm 0.380 \mathrm{~cd} \\ 0.0333 \pm 0.0003 \mathrm{bc} & 10.521 \pm 0.031 \mathrm{c} \\ 0.0164 \pm 0.0001 \mathrm{kl} & 1.161 \pm 0.086 \mathrm{jk} 1 \\ 0.0148 \pm 0.00101 & 1.081 \pm 0.167 \mathrm{kl} \\ 0.0147 \pm 0.00141 & 1.387 \pm 0.059 \mathrm{jk} \\ 0.0241 \pm 0.0014 \mathrm{hi} & 1.911 \pm 0.123 \mathrm{ij} \\ 0.0295 \pm 0.0014 \mathrm{cde} & 3.208 \pm 0.083 \mathrm{~g} \\ 0.0417 \pm 0.0009 \mathrm{a} & 12.551 \pm 0.358 \mathrm{~b} \\ 0.0283 \pm 0.0009 \mathrm{defg} & 14.211 \pm 0.206 \mathrm{a} \\ 0.0191 \pm 0.0009 \mathrm{jk} & 14.666 \pm 0.370 \mathrm{a} \\ 0.0148 \pm 0.00161 & 0.588 \pm 0.0211 \\ 0.0142 \pm 0.00051 & 0.667 \pm 0.039 \mathrm{kl} \\ 0.0140 \pm 0.00011 & 0.710 \pm 0.015 \mathrm{kl}\end{array}$


Table 5 (continued)

Concentration of ILs $\left(\mathrm{mg} \mathrm{kg}^{-1}\right.$ of soil DW)

The activity of enzymes

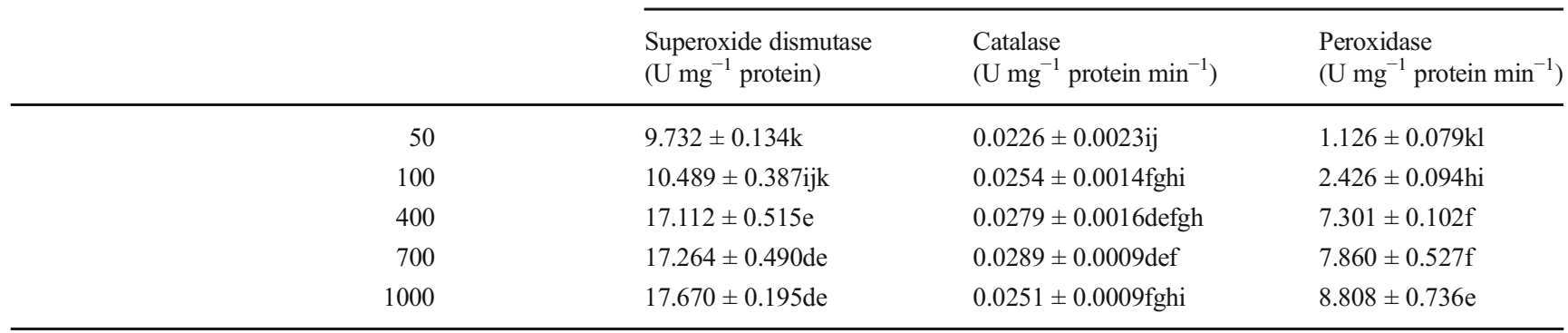

Data are expressed as a mean \pm SD of three replicates for each concentration. Values denoted by the same letters in the columns do not differ statistically at $p<0.05$

enzymes responsible for decomposition of the ROS in comparison to the observed increased enzymatic activity of peroxidase and catalase in common radish leaves.

\section{Effect of ILs on antioxidant enzyme activities}

Terrestrial plants have developed a system of antioxidant enzymes, which enables them to remove the excess ROS from the organism. The activities of SOD, CAT, POD, and glutathione reductase (GR) are correlated, since normally, the product of action of one of them constitutes an activator and substrate influencing another (Anjaneyulu et al. 2014; Gengmao et al. 2015; Sánchez-Rodríguez et al. 2010; Noqueirol et al. 2015).

In the scientific literature, a view prevails that the first line of defense against ROS is SOD, which decomposes the superoxide anion radical to $\mathrm{H}_{2} \mathrm{O}_{2}$ and $\mathrm{O}_{2}$. Therefore, the activity of the enzyme is always determined in scientific studies on the verification of the effect of oxidative stress on the biochemical and physiological changes in plants (Liu et al. 2013, 2015b, 2016a, b; Biczak 2016; Biczak et al. 2016a, b; Pawłowska and Biczak 2016; Zhang et al. 2013). Results of studies presented in the literature do not allow for reaching firm conclusions on the direction of changes in the activity of SOD in plants subject to the conditions of oxidative stress generated by ILs. The analysis of the present study results demonstrated that in spring barley seedlings, no statistically significant changes of the activity of superoxide dismutase between the control and plants cultivated in the soil with ILs' addition were observed. The observed lack of changes in SOD activity in spring barley seedlings was because the analysis was performed only at the lowest concentrations of applied ILs (1 and $10 \mathrm{mg} \mathrm{kg}^{-1}$ of soil DW). On the contrary, a considerable increase in activity of the enzyme after the use of ILs was observed in common radish leaves. The observed increase of SOD activity occurred only to certain ILs' concentration. In the highest concentrations of these salts used in the experiment, SOD activity decreased slightly; however, it always remained on the level higher than in the control (Table 5).
Similar conclusions were drawn by other authors (Cvjetko Bubalo et al. 2014a; Liu et al. 2013, 2015a, b, 2016b; Biczak 2016) who proved that the increase of SOD activity determined at lower ILs' concentrations indicates the defense of the plants against oxidative stress. On the contrary, high ionic liquid concentrations may lead to a significant damage of plant cells, which disables the introduction of antioxidant enzymes. The situation continues to reduce the possibility for antioxidant defense, eventually leading to the death of the cells and the entire plant organism.

$\mathrm{H}_{2} \mathrm{O}_{2}$ formed as a result of superoxide anion radical dismutation is digested by CAT and POD. The reaction of direct disproportionation of $\mathrm{H}_{2} \mathrm{O}_{2}$ to $\mathrm{H}_{2} \mathrm{O}$ and $\mathrm{O}_{2}$ is conducted by catalase. Despite the fact that some authors (Anjaneyulu et al. 2014; Chen et al. 2014) consider CAT as the basic enzyme responsible for the removal of $\mathrm{H}_{2} \mathrm{O}_{2}$ from plant cells, the data present in the scientific literature on the changes of activity of this enzyme are not sufficient to conclude the direction of such changes. Some authors (Cvjetko Bubalo et al. 2014a; Liu et al. 2014, 2016a, b; Pawłowska and Biczak 2016; Gengmao et al. 2015) demonstrated that CAT activity always increases under ILs' induced oxidative stress. However, in some studies (Liu et al. 2014; Sánchez-Rodríguez et al. 2010), a considerable decrease of the enzyme's activity was observed in plants subjected to oxidative stress. In spring barley seedlings, a slight increase of CAT activity was observed at the highest IL concentration (10 $\mathrm{mg} \mathrm{kg}^{-1}$ of soil DW) (Table 5).

The changes of POD activity are considered to be the most reliable biomarker indicating the occurrence of oxidative stress in plants. Regardless of the cause for oxidative stress, the activity of the enzyme always increases under the excess of $\mathrm{H}_{2} \mathrm{O}_{2}$ (Liu et al. 2013; Biczak 2016; Biczak et al. 2016a, b; Anjaneyulu et al. 2014). According to Zhang et al. (2013), the observed increase of POD activity indicates stronger affinity of the enzyme to $\mathrm{H}_{2} \mathrm{O}_{2}$ than CAT. In the discussed study, a systematic increase of POD activity was determined in spring barley seedlings and common radish leaves, growing on the soil with increasing concentration of ILs. In the highest dosages of all applied ionic liquids, the observed increase of 
peroxidase activity in common radish leaves was very high and reached several hundred percent compared to the control (Table 5). However, some studies (Arias-Baldrich et al. 2015; Wang et al. 2009) have increasingly paid attention to the fact that the increase of POD activity is not entirely favorable for plant organisms. The increased POD activity may disable plant metabolism via removal of $\mathrm{H}_{2} \mathrm{O}_{2}$ molecules, which are responsible for the cellular signaling, and lead to the damage of chlorophyll particles.

\section{Conclusion}

The analysis of the results on the influence of various ILs $\left[\right.$ Pyrrol] $\left[\mathrm{PF}_{6}\right],[\mathrm{Piper}]\left[\mathrm{PF}_{6}\right]$, and [Piryd] $\left[\mathrm{PF}_{6}\right]$ on the growth and development of spring barley and radish and the oxidative stress level allowed for drawing the following conclusions including

1. The used ILs, particularly in high concentrations, were clearly phytotoxic. Phytotoxicity depended on the plant species. Spring barley turned out to be more sensitive to the tested salts than common radish.

2. There were no significant differences in phytotoxicity of ILs with differentiated structure of cations for spring barley. In the case of common radish, modification of IL cation structure affected the size of the changes observed in selected parameters of phytotoxicity and oxidative stress. It was evident especially after the introduction of high concentrations of these salts into the soil.

3. All ILs caused a decrease of photosynthetic pigments' content in spring barley seedlings and common radish leaves, which, as a consequence, caused the decrease of yield of both plants.

4. ILs led to oxidative stress, which was followed by the MDA accumulation in both plants and increase of $\mathrm{H}_{2} \mathrm{O}_{2}$ in common radish leaves.

5. In response to stress conditions, the plants activated a system of antioxidant enzymes - SOD, CAT, and POD. The most significant enhancement of activity was observed for peroxidase, which can be considered the basic biomarker of oxidative stress in spring barley and common radish.

\footnotetext{
Acknowledgments The work was financed by a statutory activity subsidy from the Polish Ministry of Science and Higher Education for The Faculty of Environmental Management and Agriculture of West Pomeranian University of Technology in Szczecin and The Faculty of Mathematics and Natural Sciences of Jan Długosz University in Czestochowa.
}

Open Access This article is distributed under the terms of the Creative Commons Attribution 4.0 International License (http:// creativecommons.org/licenses/by/4.0/), which permits unrestricted use, distribution, and reproduction in any medium, provided you give appropriate credit to the original author(s) and the source, provide a link to the Creative Commons license, and indicate if changes were made.

\section{References}

Abassi NA, Kushad MM, Endress AG (1998) Active oxygen-scavenging enzymes activities in developing apple flowers and fruits. Sci Horti 74:183-194

Anjaneyulu E, Reddy PS, Sunita MS, Kishor PBK, Meriga B (2014) Salt tolerance and activity of antioxidative enzymes of transgenic finger millet overexpressing a vacuolar $\mathrm{H}+-$ pyrophosphatase gene (SbVPPase) from Sorghum bicolor. J Plant Physiol 171:789-798. doi:10.1016/j.jplph.2014.02.001

Arias-Baldrich C, Bosch N, Begines D, Feria AB, Monreal JA, GarcíaMauriño S (2015) Proline synthesis in barley under iron deficiency and salinity. J Plant Physiol 183:121-129. doi:10.1016/j.jplph.2015. 05.016

Atta NF, El-Ads EH, Ahmed YM, Galal A (2016) Determination of some neurotransmitters at cyclodextrin/ionic liquid crystal/graphene composite electrode. Electrochim Acta 199:319-331. doi:10.1016/j. electacta.2016.02.078

Bae S-Y, Shim E-G, Kim D-W (2013) Effect of ionic liquid as a flameretarding additive on the cycling performance and thermal stability of lithium-ion batteries. J Power Sources 244:266-271. doi:10. 1016/j. jpowsour.2013.01.100

Baunthiyal M, Pandey A (2012) Organofluorine metabolism in plants. Fluoride 45:78-85

Biczak R (2016) Quaternary ammonium salts with tetrafluoroborate anion: phytotoxicity and oxidative stress in terrestrial plants. J Hazard Mater 304:173-185. doi:10.1016/j.hazmat.2015.10.055

Biczak R, Bachowska B, Bałczewski P (2010) Study of phytotoxicity of ionic liquid 1-(methylthiomethylene)-3-butylimidazolium chloride. Proc ECOpole 4:105-114 (in Polish)

Biczak R, Bałczewski P, Bachowska B, Pawłowska B, KaźmierczakBarańska J, Cieślak M, Nawrot B (2013) Phytotoxicity and cytotoxicity of imidazolium ionic liquids containing sulfur atom. Phosphorus Sulfur Silicon Relat Elem 188:459-461. doi:10.1080/ 10426507.2012.737880

Biczak R, Bałczewski P, Pawłowska B, Bachowska B, Rychter P (2014a) Comparison of phytotoxicity of selected phosphonium ionic liquid. Ecol Chem Eng S 21:281-295. doi:10.2478/eces-2014-0022

Biczak R, Pawłowska B, Bałczewski P, Rychter P (2014b) The role anion in the toxicity of imidazolium ionic liquids. J Hazard Mater 274: 181-190. doi:10.1016/j.hazmat.2014.03.021

Biczak R, Pawłowska B, Feder-Kubis J (2015) The phytotoxicity of ionic liquids from natural pool of (-)-menthol with tetrafluoroborate anion. Environ Sci Pollut Res 22:11740-11754. doi:10.1007/s11356$015-4327-8$

Biczak R, Telesiński A, Pawłowska B (2016a) Oxidative stress in spring barley and common radish exposed to quaternary ammonium salts with hexafluorophosphate anion. Plant Physiol Biochem 107:248256. doi:10.1016/j.plaphy.2016.05.016

Biczak R, Pawłowska B, Telesiński A, Ciesielski W (2016b) The effect of the number of alkyl substituents on imidazolium ionic liquids phytotoxicity and oxidative stress in spring barley and common radish seedlings. Chemosphere 165:519-528. doi:10.1016/j.chemosphere. 2016.09.074

Bradford MM (1976) A rapid and sensitive method for the quantitation of microgram quantities utilizing the principle of protein-dye binding. Anal Biochem 72:248-254

Chapman N, Miller AJ, Lindsey K, Whalley WR (2012) Roots, water, and nutrient acquisition: let's get physical. Trends Plant Sci 17:701710. doi:10.1016/j.tplants.2012.08.001

Chen Y, Lin F, Yang H, Yue L, Hu F, Wang J, Luo Y, Cao F (2014) Effect of varying $\mathrm{NaCl}$ doses on flavonoid production in suspension cells of Ginkgo biloba: relationship to chlorophyll fluorescence, ion homeostasis, antioxidant system and ultrastructure. Acta Physiol Plant 36:3173-3187. doi:10.1007/s11738-014-1684-8 
Cho C-W, Jean Y-C, Pham TPT, Vijayaraghaven K, Sun Y-S (2008) The ecotoxicity of ionic liquids and traditional organic solvents on microalga Selenastrum capricornutum. Ecotoxicol Environ Saf 71: 166-171. doi:10.1016/j.ecoenv.2007.07.001

Couling DJ, Bernot RJ, Docherty KM, Dixon JNK, Maginn EJ (2006) Assessing the factors responsible for ionic liquid toxicity to aquatic organisms via quantitative structure-property relationship modeling. Green Chem 8:82-90. doi:10.1039/b511333d

Cvjetko Bubalo M, Hanousek K, Radošević K, Srček VG, Jakovljević T, Radojčić Redovniković I (2014a) Imidazolium based ionic liquids: effect of different anions and alkyl chains lengths on the barley seedlings. Ecotox Environ Saf 101:116-123. doi:10.1016/j.ecoenv. 2013.12.022

Cvjetko Bubalo M, Radošević K, Radojčić Redovniković I, Halambek J, Srček VG (2014b) A brief overview of the potential environmental hazards of ionic liquids. Ecotoxicol Environ Saf 99:1-12. doi:10. 1016/j.ecoenv.2013.10.019

Demidchik V (2015) Mechanisms of oxidative stress in plants: from classical chemistry to cell biology. Environ Exp Bot 109:212-228. doi:10.1016/j.envexpbot.2014.06.021

Di Baccio D, Castagna A, Tognetti R, Ranieri A, Sebastiani L (2014) Early responses to cadmium of two poplar clones that differ in stress tolerance. J Plant Physiol 171:1693-1705. doi:10.1016/j.jplph. 2014.08.007

Dragišić Maksimović J, Zhang J, Zeng F, Živanović BD, Shabala L, Zhou M, Shabala S (2013) Linking oxidative and salinity stress tolerance in barley: can root antioxidant enzyme activity be used as a measure of stress tolerance? Plant Soil 365:141-155. doi:10.1007/s11104012-1366-5

Elgharbawy AA, Alam MZ, Moniruzzaman M, Goto M (2016) Ionic liquid pretreatment as emerging approaches for enhanced enzymatic hydrolysis of lignocellulosic biomass. Biochim Eng J 109:252-267. doi:10.1016/j. bej.2016.01.021

Eyde B (1982) Determination of fluoride in plant material with ionselective electrode. Fresenius Z. Anal Chem 311:19-22

Feder-Kubis J, Tomczuk K (2013) The effect of the cationic structures of chiral ionic liquids on the their antimicrobial activities. Tetrahedron 69:4190-4198. doi:10.1016/j.tet.2013.03.107

Gengmao Z, Yu H, Xing S, Shihui L, Quanmei S, Changhai W (2015) Salinity stress increases secondary metabolites and enzyme activity in safflower. Ind Crop Prod 64:175-181. doi:10.1016/j.indcrop. 2014.10.058

Giannopolitis CN, Ries SK (1977) Superoxide dismutase. I. Occurrence in higher plants. Plant Physiol 59:309-314

Herman B, Biczak R, Gurgul E (1998) Effect of 1,10-phenanthroline on peroxidase and catalase activity and chlorophyll, sugar, and ascorbic acid contents. Biol Plant 41:607-611

Hodges DM, DeLong JM, Forney CF, Prange RK (1999) Improving the thiobarbituric acid-reactive-substances assay for estimating lipid peroxidation in plant tissues containing anthocyanin and other interfering compounds. Planta 207:604-611

Islam MK, Khanam MS, Lee SY, Alam I, Huh MR (2014) The interaction of arsenic (As) and chromium $(\mathrm{Cr})$ influences growth and antioxidant status in tossa jute (Corchorus olitorius). POJ 7:499-509

Kar M, Mishra D (1976) Catalase, peroxidase, and polyphenoloxidase activities during rice leaf senescence. Plant Physiol 57:315-319

Kumar M, Reddy CRK, Jha B (2013) The ameliorating effect of Acadian marine plant extract against ionic liquids-induced oxidative stress and DNA damage in marine macroalga Ulva lactuca. J Appl Phycol 25:369-378. doi:10.1007/s10811-012-9871-8

Liu H, Zhang S, Hu X, Chen C (2013) Phytotoxicity and oxidative stress effect of 1-octyl-3-methylimidazolium chloride ionic liquid on rice seedlings. Environ Pollut 181:242-249. doi:10.1016/j.envpol.2013. 06.007

Liu T, Zhu L, Xie H, Wang J, Wang J, Sun F, Wang F (2014) Effects of the ionic liquid 1-octyl-3-methylimidazolium hexafluorophosphate on the growth of wheat seedlings. Environ Sci Pollut Res 21:39363945. doi:10.1007/s11356-013-2348-8

Liu H, Zhang S, Zhang X, Chen C (2015a) Growth inhibition and effect on photosystem by three imidazolium ionic liquids in rice seedlings. J Hazard Mater 286:440-448. doi:10.1016/j.hazmat.2015.01.008

Liu T, Zhu L, Wang J, Wang J, Xie H (2015b) The genotoxic and cytotoxic effects of 1-butyl-3-methylimidazolium chloride in soil on Vicia faba seedlings. J Hazard Mater 285:27-36. doi:10.1016/j. hazmat.2014.11.028

Liu T, Wang J, Wang J, Zhu L, Zhang J, Sun X (2016a) Growth and physiological and biochemical responses of wheat seedlings to imidazolium-based ionic liquids 1-octyl-3-methylimidazolium chloride and 1-oktyl-3-methylimidazolium bromide. Bull Rnviron Contam Toxicol 96:544-549. doi:10.1007/s00128-016-1747-1

Liu T, Zhu L, Wang J, Wang J, Tan M (2016b) Phytotoxicity of imidazolium-based ILs with different anions in soil on Vicia faba seedlings and the influence of anions on toxicity. Chemosphere 145: 269-276. doi:10.1016/j.chemosphere.2015.11.055

Ma J-M, Cai L-L, Zhang B-J, Hu L-W, Li X-Y, Wang J-J (2010) Acute toxicity ond effects of 1-alkyl-3-methylimidazolium bromide ionic liquids on green algae. Ecotox Environ Saf 73:1465-1469. doi:10. 1016/j.ecoenv.2009.10.004

Matusiak A, Lewkowski J, Rychter P, Biczak R (2013) Phytotoxicity of new furan-derived aminophosphonic acid, $\mathrm{N}$-aryl furaldimines and 5-nitrofuraldimine. J Agric Food Chem 61:7673-7678. doi:10. 1021/jf402401z

Matzke M, Stolte S, Arning J, Uebers U, Filser J (2008a) Imidazolium based ionic liquids in soil: effects of the side chain length on wheat (Triticum aestivum) and cress (Lepidum sativum) as affected by different clays and organic matter. Green Chem 10:584-591. doi:10. 1039/b717811e

Matzke M, Stolte S, Böschen A, Filser J (2008b) Mixture effects and predictability of combination effects of imidazolium based ionic liquids as well as imidazolium based ionic liquids and cadmium on terrestrial plants (Triticum aestivum) and limnic green algae (Scenedesmus vacuolatus). Green Chem 10:784-792. doi:10.1039/ b802350f

Matzke M, Stolte S, Arning J, Uebers U, Filser J (2009) Ionic liquids in soil: effects of different anion species of imidazolium based ionic liquids on wheat (Triticum aestivum) as affected by different clay minerals and clay concentrations. Ecotoxicology 18:197-203. doi: 10.1007/s10646-008-0272-3

Messali M, Moussa Z, Alzahrani AY, El-Naggar MY, El Douhaibi AS, Judeh ZMA, Hammouti B (2013) Synthesis, characterization and the antimicrobial activity of new eco-friendly ionic liquids. Chemosphere 91:1627-1634. doi: 10.1016/j.chemosphere.2012. 12.062

Mrozik W, Jungnickel C, Ciborowski T, Pitner WR, Kumirska J, Kaczyński Z, Stepnowski P (2009) Predicting mobility of alkylimidazolium ionic liquids in soils. J Soils Sediments 9:237245. doi: 10.1007/s11368-009-0057-1

Noqueirol RC, Monteiro FA, Gratão PL, Borgo L, Azevedo RA (2015) Tropical soil with high aluminium concentrations cause oxidative stress in two tomato genotypes. Environ Monit Assess 187:73. doi: 10.1007/s10661-015-4282-3

OECD (2006) Guidelines for the Testing of Chemicals, Section 2, Test No. 208: Terrestrial Plant Test: Seedling Emergence and Seedling Growth Test. doi: 10.1787/20745761

Oren R, Werk KS, Buchmann N, Zimmermann R (1993) Chlorophyllnutrient relantionships identify nutritionally caused decline in Picea abies stands. Can J For Res 23:1187-1195

Oukarroum A, Bussotti F, Goltsev V, Kalaji HM (2015) Correlation between reactive oxygen species production and photochemistry of photosystems I and II in Lemna gibba L. plants under salt stress. Environ Exp Bot 109:80-88. doi:10.1016/j.envexpbot.2014.08.005 
Pandey PC, Kumar P, Rani M, Katiyar S, Tomar V (2014) Fluorideinduced impact of aluminium industrial power plant on plants and human inhabiting areas. Geofizika 31:151-168. doi:10.15233/gfz. 2014.31.8

Pawłowska B, Biczak R (2016) Evaluation of the effect of tetraethylammonium bromide and chloride on the growth and development of terrestrial plants. Chemosphere 149:24-33. doi:10. 1016/j.chemosphere.2016.01.072

Peric B, Sierra J, Martí E, Cruañas R, Garau MA, Arning J, Bottin-Weber U, Stolte S (2013) (Eco)toxicity and biodegradability of selected protic and aproticionic liquids. J Hazard Mater 261:99-105. doi: 10.1016/ j.jhazmat.2013.06.070

Petkovic M, Hartmann DO, Adamová G, Seddon KR, Rebelo LPN, Silva Pereira C (2012) Unravelling the mechanism of toxicity of alkyltributylphosphonium chlorides in Aspergillus nidulans conidia. New J Chem 36:56-63. doi:10.1039/c1nj20470j

Pham TPT, Cho C-W, Yun Y-S (2010) Environmental fate and toxicity of ionic liquids: a review. Water Res 44:352-372. doi:10.1016/j. watres.2009.09.030

Pham TPT, Cho C-W, Yun Y-S (2016) Structural effects of ionic liquids on microalgal growth inhibition and microbial degradation. Environ Sci Pollut Res 23:4249-4300. doi:10.1007/s11356-015-5287-8

Radošević K, Cvjetko Bubalo M, Srček VG, Grgas D, Dragičević TL, Radojčić Redovniković I (2015) Evaluation of toxicity and biodegradability of cholone chloride based deep eutectic solvents. Ecotoxicol Environ Saf 112:46-53. doi:10.1016/j.ecoenv.2014.09. 034

Rosalie R, Joas J, Deytieux-Belleau C, Vulcain E, Payet B, Dufossé L, Léchaudel M (2015) Antioxidant and enzymatic responses to oxidative stress induced by pre-harvest water supply reduction and ripening on mango (Mangifera indica L. cv. 'Cogshall') in relation to carotenoid content. J Plant Physiol 184:68-78. doi:10.1016/j. jplph.2015.05.019
Sánchez-Rodríguez E, Rubio-Wilhelmi MM, Cervilla LM, Blasco B, Rios JJ, Rosales MA, Romero L, Ruiz JM (2010) Genotypic differences in some physiological parameters symptomatic for oxidative stress under moderate drought in tomato plants. Plant Sci 178:30 40. doi:10.1016/j.plantsci.2009.10.001

Schubert BA, Jahren AH (2011) Fertilization trajectory of the root crop Raphanus sativus across atmospheric $\mathrm{pCO}_{2}$ estimates of the next 300 years. Agric Ecosyst Environ 140:174-181. doi:10.1016/j. agee.2010.11.024

Singh HP, Batish DR, Kohli RK, Arora K (2007) Arsenic-induced root growth inhibition in mung bean (Phaseolus aureus Roxb.) is due to oxidative stress resulting from enhanced lipid peroxidation. Plant Growth Regul 53:65-73. doi:10.1007/s10725-007-9205-Z

Stolte S, Matzke M, Arning J, Böschen A, Pitner W-R, Welz-Biermann U, Jastorff B, Ranke J (2007) Effects of different head groups and functionalised sidechains on the aquatic toxicity of ionic liquids. Green Chem 9:1170-1179. doi:10.1039/b711119c

Studzińska S, Buszewski B (2009) Study of toxicity of imidazolium ionic liquids to watercress (Lepidium sativum L.) Anal Bioanal Chem 393:983-990. doi:10.1007/s00216-008-2523-9

Studzińska S, Kowalkowski T, Buszewski B (2009) Study of ionic liquid cations transport in soil. J Hazard Mater 168:1542-1547. doi:10. 1016/j.hazmat.2009.03.029

Telesiński A, Śnioszek M (2009) Bioindicators of environmental pollution with fluorine. Bromatol Chem Toksykol 4:1148-1154 In Pol.

Wang L-S, Wang L, Wang L, Wang G, Li Z-H, Wang J-J (2009) Effect of 1-butyl-3-methylimidazolium tetrafluoroborate on the wheat (Triticum aestivum L.) seedlings. Environ Toxicol 24:296-303. doi:10.1002/tox.20435

Zhang B, Li X, Chen D, Wang J (2013) Effects of 1-octyl-3methylimidazolium bromide on the antioxidant system of Lemna minor. Protoplasma 250:103-110. doi:10.1007/s00709-012-0379-5 